\title{
Reproduction, pollination and seed predation of Senna multijuga (Fabaceae) in two protected areas in the Brazilian Atlantic forest
}

\author{
Marina Wolowski ${ }^{1} \&$ Leandro Freitas ${ }^{2}$ \\ 1. Programa de Pós-Graduação em Botânica, Instituto de Pesquisas Jardim Botânico do Rio de Janeiro, rua Pacheco Leão \\ 2040, CEP 22460-030, Rio de Janeiro, RJ, Brasil; marina.wolowski@gmail.com \\ 2. Instituto de Pesquisas Jardim Botânico do Rio de Janeiro, rua Pacheco Leão 915, CEP 22460-030, Rio de Janeiro, RJ, \\ Brasil; leandro@jbrj.gov.br
}

Received 25-X-2010. C Corrected 20-III-2011. Accepted 26-IV-2011.

\begin{abstract}
One important subject is to determine the effectiveness of conservation areas, where different management categories are being applied, to maintain effective sexual reproduction in plants and their interactions with animal groups. To evaluate this issue, we compared the phenology, reproductive success, pollination and pre-dispersal seed predation of the legume tree Senna multijuga in two differently managed protected areas in Southeastern Brazil: the Itatiaia National Park and the Environmental Protection Area of Serrinha do Alambari, from December 2007 to December 2008. Vegetative and reproductive phenodinamycs were registered monthly in 80 individuals; other evaluations included 104 observation hours for pollination (March-May 2008) in 51 inflorescences; besides, fruit counts, fecundity and seed predation. Sexual reproduction of S. multijuga depends on the transfer of pollen by large bees (Bombus, Centris, Epicharis and Xylocopa), as the species is self-incompatible. Bruchidae species of the genus Acanthoscelides and Sennius predate seeds. Vegetative and reproductive phenodynamics differed among sites. Our results indicated that ecological interactions were lower at the protected area, but the reproductive processes in S. multijuga were not ruptured or critically degraded. This reinforces the idea that landscape areas with intermediate levels of protection, such as environmental protection areas, are suitable as buffer zones, and thus, relevant to the conservation of ecological processes when associated with more strictly protected areas. Rev. Biol. Trop. 59 (4): 1939-1948. Epub 2011 December 01.
\end{abstract}

Key words: bee pollination, biodiversity conservation, bruchids, fecundity, fruit set, Leguminosae, phenology.

One of the major strategies for the conservation of biodiversity is the establishment of protected areas, but it is recognised that there is a variety of approaches to establishing and managing such areas important to conservation, and what may be applicable in one place may not be in another (Dudley 2008). Although different kinds of protected areas can meet the general purposes defined in the categorisation by the International Union for Conservation of Nature (IUCN) (Dudley 2008), the management activities within protected areas and the threats to the natural and cultural resources are distinct; moreover, they may differ in their conservation effectiveness (Hockings 2003,
Gaston et al. 2008). Current knowledge on the extent to which protected areas fulfil their biodiversity protection goals is poor worldwide (Gaston et al. 2006), and there are few field assessments of the ecological effectiveness of protected areas (Brown et al. 2009). Protection effectiveness can be understood in terms of the different levels of hierarchical organization of biodiversity and the associated processes or functions, and it can be examined at several spatial scales (Gaston et al. 2006, 2008).

In spite of these many possibilities, the species is the most commonly used operational unit when addressing questions on biodiversity conservation (Scarano 2007). Inventories 
of the amount of biodiversity (i.e., number of species and ecosystems or communities) present in protected areas are the most common method used to assess their ecological effectiveness, and this practice is based on the assumption that inventory measures provide an indirect indication of condition of ecological processes within protected areas (Gaston et al. 2006). Nevertheless, criticism of the supposed relationship between biodiversity and ecosystem function (Srivastava \& Vellend 2005, Scarano 2007) highlights the need for more direct measures of the persistence of biodiversity elements within protected areas. For instance, reproductive viability and mutualistic and antagonistic interactions are relevant indicators of the functioning and viability of plant populations in protected areas (Pauw 2007). However, to our knowledge, there is a lack of comparative studies on the effectiveness of protected areas with varying levels of restrictions (i.e., different management categories) in maintaining sexual reproduction in plants and their interactions with animals.

Here, we compare plant-animal interactions and the reproductive success of Senna multijuga (Rich.) Irwin \& Barneby in two protected areas of different management categories (after the Brazilian National System of Protected Areas - SNUC, Brasil 2000) in the Atlantic forest. Senna multijuga is a mediumsized legume tree that frequently occurs in secondary forests, clearings, edges, regeneration areas and pastures (Irwin \& Barneby 1982). It is self-incompatible and depends on bees for its pollination (Wolowski \& Freitas 2010). Replanting this species is recommended when restoring degraded areas, as it is an aggressive pioneer, with moderate longevity and good capacity of hindering the emergence of invasive grasses (Kalil-Filho et al. 2002). Senna multijuga is also recognized as an important species for ecological interactions, for instance, it is a notable host for cicadas, and therefore, armadillos commonly make holes in the base of its trunk looking for the nymphs (Carvalho 2004); its leaves, flowers and fruits are sources of food for the spider-monkey (Brachyteles arachnoids, Mendonça-Filho 1996) and its seeds are often damaged before dispersal by Bruchidae beetles (Sari \& Ribeiro-Costa 2005, Sari et al. 2005). In addition, it is important as a source of pollen for bees, especially Centridini species, due to its extended flowering (Wolowski \& Freitas 2010), as well as its flowers, leaves and fruits are destroyed by Trigona spinipes (Meliponini, Almeida \& Laroca 1988).

The Brazilian Atlantic Forest is a vast heterogeneous region (about 1.5 million $\mathrm{km}^{2}$ ), including a large variety of vegetation types and assemblages, large numbers of species (1-8\% of the world's total species), and numerous endemic species (Myers et al. 2000, Metzger 2009). This biome is highly imperilled and constitutes one of the most important biodiversity hotspots on Earth (Laurance 2009). Only $1.6 \%$ of the entire region is contained within protected areas, and these safeguard $9.3 \%$ of the remaining vegetation (11.7\% of the original cover) (Ribeiro et al. 2009). We choose two contiguous protected areas in the Atlantic forest as our study system. The first is a national park, which has the aim of ecosystem protection and prohibits any direct use of natural resources. The second unit is an environmental protection area that is equivalent to the "protected landscape" according to the IUCN's categories (Dudley 2008), which aims to maintain a harmonious interaction between nature and culture through the protection of landscapes and the continuation of traditional land uses, building practices and social and cultural manifestations. The two areas also differ in size and forest age, and in the degree of conservation, human presence and natural resources exploitation. Because of differences in the successional stage of and historical land use between the two areas, we expected higher effectiveness in the conservation of interactions within the more restrictive protected area. Specifically, we evaluated the phenology, pollination, reproductive success and pre-dispersal seed predation of Senna multijuga in those two areas. 


\section{MATERIALS AND METHODS}

Study areas: The Itatiaia National Park (INP, Fig. 1) was created in 1937 and is the oldest national park in the country with an area of 30 000ha. The Environmental Protection Area of Serrinha do Alambari (EPASA, Fig. 1) is 4 500ha and a more recently (1991) protected area of Resende county (Rio de Janeiro state), and it is located in the buffer zone of INP. The vegetation in the INP at the study site $\left(22^{\circ} 27^{\prime}\right.$ S - 44 $36^{\prime}$ ' W, altitude between $800 \mathrm{~m}$ and $900 \mathrm{~m}$ ) is classified as montane broadleaf rainforest (Veloso et al. 1991). The climate is subtropical humid ( $C w a$ and $C f b$, after Köeppen classification) with a mean annual rainfall of $1699 \mathrm{~mm}$ and a mean annual temperature of $18.2^{\circ} \mathrm{C}$ (Segadas-Vianna \& Dau 1965). The altitudinal range, climate and vegetation in the EPASA $\left(22^{\circ} 23^{\prime} \mathrm{S}-44^{\circ} 32^{\prime} \mathrm{W}\right)$ are similar to the INP, but the areas differ in the successional stages of the vegetation. Historically, the EPASA area was used for wood extraction, coffee plantations and ranching, and human presence has increased since the 1970s. Currently, there are secondary forests adjacent to INP at higher altitudes (above $1000 \mathrm{~m}$ ), as well as regeneration areas and residencies about $800 \mathrm{~m}$ and pastures about $500 \mathrm{~m}$. EPASA is divided into four zones, two of them have restrictive uses (wildlife protection and self-sustained management) and the other two allow intensive uses (residences and pastures). Hereafter, we call those as EPASA I and EPASA II, respectively.

Study species: Senna multijuga is a medium-sized tree 10 to $15 \mathrm{~m}$ in height that frequently occurs at altitudes between $50 \mathrm{~m}$ and

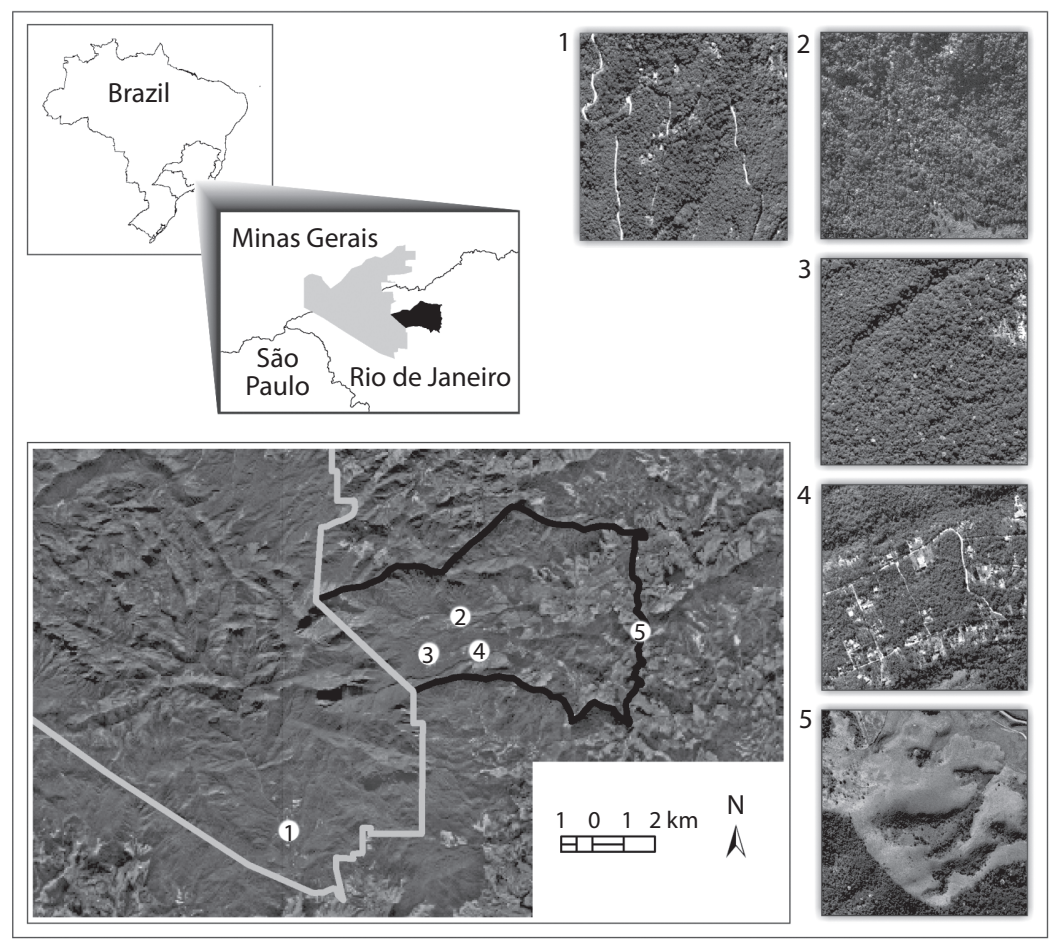

Fig. 1. Itatiaia National Park (grey) between Rio de Janeiro and Minas Gerais states and the Environmental Protection Area of Serrinha do Alambari (black) at Rio de Janeiro state, Southeastern Brazil. Studied area and sampling points: 1) represents the studied area in Itatiaia National Park (grey line); 2 to 5) represents studied areas in the Environmental Protection Area of Serrinha do Alambari (EPASA) (black line); 2 and 3) areas with restrictive uses in EPASA I; 4 and 5) residencies and pastures in EPASA II, respectively. 
950m in secondary forests, clearings, edges, regeneration areas and pastures from Central to South America (Irwin \& Barneby 1982). Inflorescences are terminal panicules that bear hermaphrodite and zygomorphous flowers. Flowers have a yellow corolla with a mean diameter of $36.8 \pm 2.5 \mathrm{~mm}$ (mean \pm standard deviation throughout the text) $(\mathrm{n}=10)$, diurnal anthesis, heteranthery, poricide dehiscence, and pollen as the only resource. Voucher (MWTorres 4) is deposited in the herbarium RB on Botanical Garden of Rio de Janeiro.

Only certain bees with the ability to vibrate can pollinate flowers with these characteristics (Buchmann 1983). Accordingly, pollinators of $S$. multijuga are large bees belonging to the genera Bombus, Centris, Epicharis and Xylocopa (Wolowski \& Freitas 2010). Sexual reproduction depends on the transfer of pollen by pollinators, as no fruit is formed by selfpollination due to either inbreeding depression or by a mechanism of late-acting self-incompatibility (Wolowski \& Freitas 2010). Seeds are predated by Bruchidae species of the genera Acanthoscelides and Sennius (Sari \& RibeiroCosta 2005, Wolowski unpubl. res.).

Phenology: Vegetative and reproductive phenodynamics were registered monthly from December 2007 to December 2008 in 80 individuals, respectively, 19 from INP, 38 from EPASA I and 23 from EPASA II. Presence and intensity of leaf flushing, leaf fall, floral buds, open flowers, and immature and mature fruits were recorded with binoculars. The Fournier's percentage index of intensity (Fournier 1974) and the activity index (Bencke \& Morellato 2002) were calculated.

Fecundity and seed predation: 15 mature fruits per individual were collected prior to opening (in July and August 2008) from a total of 19 individuals, respectively, five from INP, seven from EPASA I and seven from EPASA II. They were dissected with nippers and stiletto and the number of non-developed ovules (i.e., scars of ovules) and seeds were counted with the help of a stereomicroscope. The number of developed seeds, aborted seeds (i.e., with incomplete development), predated seeds (i.e., developed seeds with the presence of bruchids or with predation orifices), and non-predated seeds were also counted. The total number of ovules (i.e., the sum of non-developed ovules, developed seeds, and aborted seeds) was calculated.

The following reproductive parameters were estimated: gross fecundity (number of developed seeds per total number of ovules), seed abortion (number of aborted seeds per total number of ovules), seed predation (number of predated seeds per number of developed seeds), and effective fecundity (number of non-predated seeds per total number of ovules).

Pollination and fruit set: The number of visits by pollinators and number of visited flowers were recorded between March and May 2008. Data were taken between 8a.m. and 1 p.m. on different days with clear or partially covered sky (total of $104 \mathrm{hr}$ of observation). Two to five inflorescences per individual were observed with binoculars and telescopes for two hours per inflorescence at $15 \mathrm{~min}$ intervals. Inflorescences were observed from individuals in their flowering peak, defined by flowering intensity equal or superior to 3 on the Fournier's scale. A total of 16 inflorescences from four individuals at INP, 18 inflorescences from six individuals at EPASA I, and 17 inflorescences from six individuals from EPASA II were observed. Fruit set was estimated for each inflorescence by counting well-developed fruits fortnightly for a two-month period.

Original and transformed data were tested for normality and homoscedasticity, and nonparametric statistical tests were performed in Statistica 6.0 (Statsoft 2001). The Wilcoxon paired sample test was used to compare phenodynamics between sites. The KruskalWallis test $(\mathrm{H})$ was used to compare all variables (fecundity, seed predation, pollination and fruit set) among sites and to verify possible differences in floral visitation among time intervals of observation in each area. 
Significant pairwise difference was tested with multiple comparisons.

\section{RESULTS}

Phenology: Leaf flushing was not observed from April to August at INP, and it was sparse $(<30 \%)$ at EPASA I and II in the same period (Fig. 2). Leaf fall was similar between the two areas and constant over time (Fig. 2), except from October to December. Activity and intensity indices of vegetative phases were statistically different $(\mathrm{p}<0.05)$ between the pairs INP-EPASA I (flush activity: $Z=2.97$; flush intensity: $Z=3.18$; fall activity: $Z=2.55$; fall intensity: $Z=2.49$ ) and INP-EPASA II (flush activity: $Z=2.93$; flush intensity: $Z=3.18$; fall activity: $Z=2.50$; fall intensity: $Z=2.04$ ). Leaf flushing activity at EPASA I differed from EPASA II $(Z=2.40 ; \mathrm{p}<0.05)$.

Flowering was annual with intermediary duration (sensu Newstrom et al. 1994). Flowering time differed between the areas, with a brief overlap (Fig. 2). Flowering peaks were two months apart. Fruit development started in March and extended to June at INP, while it was from April to August at EPASA I and II (Fig. 2). The timing of seed dispersal also differed, as the intensity of mature fruits was higher in June and July at INP and in August and September at EPASA I and II (Fig. 2). Activity and intensity indices of reproductive phases
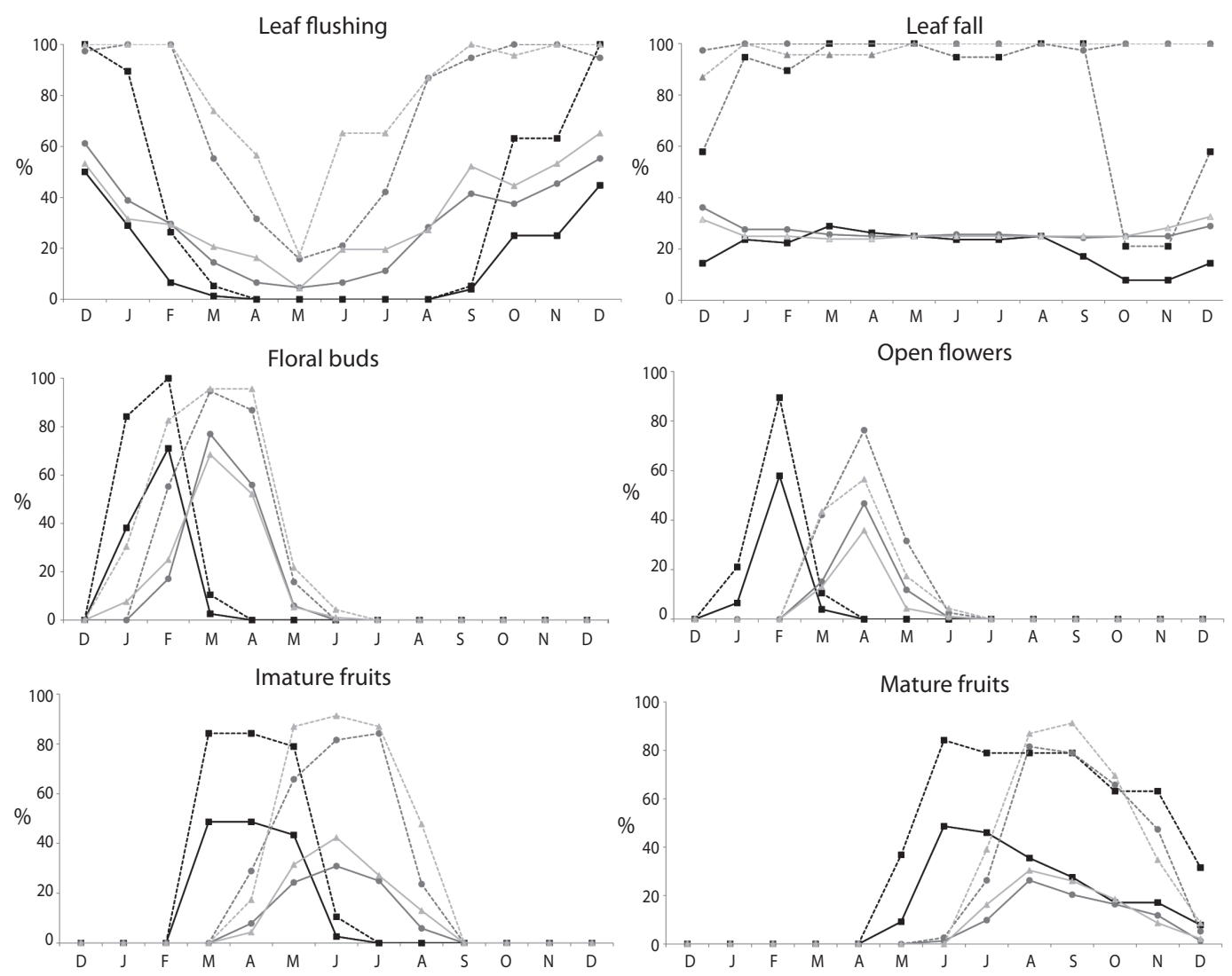

Fig. 2. Graphic representation of Fournier's percent index of intensity (full line) and the activity index (dotted line) of vegetative (A and B) and reproductive phases (C to F) of Senna multijuga at Itatiaia National Park (black $\mathbf{\square})$ and the Environmental Protection Area of Serrinha do Alambari: EPASA I (dark gray ) and EPASA II (gray $\triangle$ ) from December 2007 to December 2008. A. Leaf flushing. B. Leaf fall. C. Floral buds. D. Open flowers. E. Immature fruits. F. Mature fruits. 
did not differ between sites ( $p>0.05$ ), except floral buds activity between EPASA I and II $(Z=2.20 ; p<0.05)$ and mature fruits intensity between INP and EPASA I $(Z=2.52 ; p<0.05)$ and between INP and EPASA II $(\mathrm{Z}=2.38$; $\mathrm{p}<0.05)$.

Fecundity and seed predation: Differences in overall fecundity were detected among the three sites; gross fecundity was higher at INP and EPASA II, and effective fecundity was higher at EPASA II (Table 1). Although the total number of ovules was higher at EPASA I and II, and the number of predated seeds and seed predation were higher at INP (Table 1).

Pollination and fruit set: The number of visits by pollinators was comparable among the different periods of observation for each site (INP: $\mathrm{H}=0.69, \mathrm{p}=0.98$; EPASA I: $\mathrm{H}=8.29$, $\mathrm{p}=0.22$; EPASA II: $\mathrm{H}=8.95, \mathrm{p}=0.18$ ). Thus, we merged the data and compared the accumulated frequencies among the inflorescences from the three sites. The frequency of visits and the number of flowers visited per hour were different among sites (Table 1). This difference was significant between INP and EPASA I (visits/hour and flowers visited/hour; $\mathrm{p}<0.001$ ) and, between EPASA I and EPASA II (visits/hour; $\mathrm{p}=0.02$ and flowers visited/hour; $\mathrm{p}=0.01$ ) (Table 1). Fruit set was similar among sites (Table 1).

\section{DISCUSSION}

The delayed occurrence of leaf flushing at EPASA may be due to differences in microclimate between the studied sites (Saunders et al. 1991, Murcia 1995), such as the higher solar radiation and temperatures at EPASA. Vegetative phenophases can have time-lag effects on reproductive phenology (Borchert 1992). This seems to be the case for S. multijuga, as it flowers after leaf flushing, which may explain the delayed flowering peak at EPASA. The time of fruit development and maturation of

TABLE 1

Fecundity, seed predation, pollination and fruit set parameters of Senna multijuga at Itatiaia National Park (INP) and the Environmental Protection Area of Serrinha do Alambari (EPASA)

\begin{tabular}{|c|c|c|c|c|c|}
\hline & $\begin{array}{c}\text { INP } \\
n=5,75\end{array}$ & $\begin{array}{l}\text { EPASA I } \\
n=7,105\end{array}$ & $\begin{array}{c}\text { EPASA II } \\
n=7,105\end{array}$ & H Statistic & $\mathrm{P}$ \\
\hline Total number of ovules & $45.07 \pm 6.14^{\mathrm{a}}$ & $53.82 \pm 5.62^{\mathrm{b}}$ & $52.09 \pm 4.72^{b}$ & 82.58 & $<0.001$ \\
\hline Developed seeds & $27.29 \pm 9.31^{\mathrm{c}, \mathrm{d}}$ & $24.64 \pm 10.18^{c}$ & $28.69 \pm 9.41^{\mathrm{d}}$ & 8.38 & 0.015 \\
\hline Non predated seeds & $17.23 \pm 7.66^{\mathrm{e}}$ & $20.17 \pm 11.41^{\mathrm{e}}$ & $24.66 \pm 9.78^{f}$ & 24.93 & $<0.001$ \\
\hline Predated seeds & $10.07 \pm 8.37^{\mathrm{g}}$ & $4.47 \pm 4.54^{\mathrm{h}}$ & $4.03 \pm 4.69^{\mathrm{h}}$ & 41.96 & $<0.001$ \\
\hline Aborted seeds & $6.47 \pm 4.27^{\mathrm{i}}$ & $11.88 \pm 8.12^{\mathrm{j}}$ & $8.65 \pm 7.18^{i}$ & 23.33 & $<0.001$ \\
\hline Gross fecundity & $0.60 \pm 0.17^{1}$ & $0.46 \pm 0.19^{\mathrm{m}}$ & $0.55 \pm 0.18^{1}$ & 24.49 & $<0.001$ \\
\hline Effective fecundity & $0.38 \pm 0.16^{\mathrm{n}}$ & $0.38 \pm 0.21^{\mathrm{n}}$ & $0.48 \pm 0.19^{\circ}$ & 14.44 & $<0.001$ \\
\hline Seed predation & $0.35 \pm 0.22^{p}$ & $0.23 \pm 0.26^{\mathrm{q}}$ & $0.14 \pm 0.17^{\mathrm{r}}$ & 43.90 & $<0.001$ \\
\hline \multirow[t]{2}{*}{ Seed abortion } & $0.15 \pm 0.11^{\mathrm{s}}$ & $0.22 \pm 0.15^{\mathrm{t}}$ & $0.16 \pm 0.13^{\mathrm{s}}$ & 13.18 & 0.0014 \\
\hline & $\mathrm{N}=16$ & $\mathrm{~N}=18$ & $\mathrm{~N}=17$ & & \\
\hline Visits/hour & $3.45 \pm 2.01^{\mathrm{a}}$ & $0.72 \pm 1.19^{\mathrm{b}}$ & $2.21 \pm 1.94^{\mathrm{a}}$ & 18.25 & $<0.001$ \\
\hline Flowers/hour & $7.7 \pm 5.71^{\mathrm{c}}$ & $1.14 \pm 2.03^{\mathrm{d}}$ & $4.35 \pm 4.40^{\mathrm{c}}$ & 18.57 & $<0.001$ \\
\hline Fruits/inflorescence & $3.19 \pm 3.85^{\mathrm{e}}$ & $2.39 \pm 2.48^{\mathrm{e}}$ & $2.41 \pm 4.48^{\mathrm{e}}$ & 1.29 & 0.52 \\
\hline
\end{tabular}

Gross fecundity (developed seeds/total number of ovules), effective fecundity (non-predated seeds/total number of ovules), seed predation (predated seeds/developed seeds), seed abortion (aborted seeds/total number of ovules).

Data are means \pm standard deviation; $n=$ number of individuals, number of fruits; $\mathrm{N}=$ number of inflorescences. 
S. multijuga differed between areas. However, seed dispersal was in the dry season in both areas, when conditions are more favourable for anemocoric species (Frankie et al. 1974).

Effective fecundity affects other phases of the plant life cycle the most because it directly influences population recruitment. This parameter was higher in EPASA II than INP, because antagonistic interactions were more intense at the latter. It means that the relative reproductive success of $S$. multijuga reflects the balance between pollination and seed predation.

Pollinators are fundamental to the reproduction of $S$. multijuga (Wolowski \& Freitas 2010). Pollination differences may be associated with factors that regulate bee populations, such as plant resources and nest sites in fragmented areas (Aizen \& Feinsinger 1994b, Tscharntke et al. 1998, Cane 2001, Goulson et al. 2008, Steffan-Dewenter \& Schiele 2008). Although differences in reproductive success may not be related to fragmentation (Aizen \& Feinsinger 1994a, Dick 2001, Lopes \& Buzato 2007, Ramos \& Santos 2006, Dunley et al. 2009), pollination reduction negatively affects reproductive success in many selfincompatible species in fragmented habitats (Aizen \& Feinsinger 1994a, Ghazoul et al. 1998, Gigord et al. 1999, Steffan-Dewenter et al. 2002, Aguilar \& Galetto 2004, Aguilar et al. 2006). Then, we expected lower levels of pollination in EPASA II, because its intensive use of natural resources, but this was not observed. High frequency of visits to Senna multijuga in EPASA II may be due to lower richness and abundance of plant species and so fewer pollen resources for bees.

In contrast, higher seed predation at INP and EPASA I is consistent with other studies in which herbivory was greater in habitats with more vegetation cover (Cascante et al. 2002, Kolb et al. 2007, Herrerías-Diego et al. 2008). Specialisation, short life cycles and phenology synchronisation with the host plant can affect the population dynamics of bruchid species (Harper 1977) (i.e. the predators of seeds of $S$. multijuga). Moreover, these insects are sensitive to fluctuations in food resources and variation of abiotic factors, such as luminosity and humidity (Cascante et al. 2002, Lewis \& Basset 2007).

Our results indicated that the ability to maintain ecological interactions in EPASA was lower than INP. However, the lower effectiveness of EPASA was not associated with the critical degradation of reproduction and interactions of $S$. multijuga in this protected area. Landscape ecology highlights the importance of matrix composition on fragmentation effects (Bissonette \& Storch 2002), and a matrix containing forests at initial regeneration stages potentially provides greater functional connectivity than agricultural and grazing matrices (Umetsu \& Pardini 2007). Thus, increasing semi-natural habitat in the landscape may promote high levels of pollination and predation (Steffan-Dewenter et al. 2001, 2002). In this context, the habitat heterogeneity at EPASA, including open areas and secondary forests in regeneration, potentially facilitates the persistence of the ecological processes linked to $S$. multijuga. These reinforces the idea that landscape areas with intermediate levels of protection, such as environmental protection areas, are suitable as buffer zones, and thus, are relevant to the conservation of ecological processes when associated with more strictly protected areas.

Senna multijuga is a widely distributed generalist species common in forests in the initial and late secondary successional stages. These aspects may bias in support of our main conclusion on the similarity of biodiversity processes in the two studied areas. In addition, the variation coefficient of measured variables (pollination, fruit set and seed predation) was high, suggesting that additional sampling effort is required for a more robust evaluation. However, these are the first results evaluating the effectiveness of protected areas with distinct management categories on the persistence of ecological interactions in the Atlantic forest. Future studies should evaluate other aspects of ecosystem conservation in protected area networks in this hotspot, such as the maintenance of population dynamics, the persistence and 
viability of species assemblages, disturbance and the succession dynamics of communities, and ecosystem services (Gaston et al. 2006).

\section{ACKNOWLEDGMENTS}

We thank G. Bernadello, P.E.A.M. Oliveira and A.P. Fernandez for comments on the first version of this manuscript, V.S. Silvestre and L. Silva for field support, M.A. Santos, E.F. Gomes and M. Siqueira for mapping support and PROAP-CAPES and PETROBRAS-PMA for financial support. LF thanks CNPq for a researcher grant. This paper is part of the MSc dissertation of the first author presented to the 'Programa de Pós-Graduação em Botânica, Instituto de Pesquisas Jardim Botânico do Rio de Janeiro.

\section{RESUMEN}

Es importante determinar la eficacia de las áreas de conservación cuando se están implementando diferentes categorías de manejo, y una forma de hacerlo es conociendo si se mantiene una reproducción sexual efectiva en las especies de plantas y sus interacciones con grupos de animales. Para evaluar esta cuestión, se comparó la fenología, el éxito reproductivo, la polinización y la pre-dispersión de semillas depredadas de la leguminosa Senna multijuga en dos áreas protegidas sometidas a diferente tipos de manejo en el sureste de Brasil: el Parque Nacional de Itatiaia y el Área de Protección Ambiental de Serrinha de Alambari, de diciembre 2007 a diciembre 2008. La fenodinámica vegetativa y reproductiva fue registrada mensualmente en 80 individuos; otras evaluaciones incluyeron 104 horas de observación de la polinización (marzo-mayo 2008) en 51 inflorescencias, además del conteo de frutos, fecundidad y depredación de semillas. S. multijuga tiene una reproducción sexual que depende de la polinización de abejas grandes (Bombus, Centris, Epicharis y Xylocopa) y se considera una especie auto-incompatible. Las semillas son depredadas por especies de Bruchidae de los géneros Acanthoscelides y Sennius. La fenodinámica vegetativa y reproductiva difirió entre sitios. Nuestros resultados indican que las interacciones ecológicas fueron menores en el área protegida, pero los procesos reproductivos de $S$. multijuga no se vieron interrumpidos ni degradados de manera crítica. Esto refuerza la idea de que las zonas de paisaje con niveles intermedios de protección, tales como las áreas de protección ambiental, son adecuadas como zonas de amortiguamiento, y por lo tanto, relevantes para la conservación de los procesos ecológicos cuando se asocian con áreas en las que se da una protección más estricta.
Palabras clave: polinización de abejas, conservación de la biodiversidad, brúquidos, fecundidad, fructificación, frutos, Leguminosae, fenología.

\section{REFERENCES}

Aguilar, R. \& L. Galetto. 2004. Effects of forest fragmentation on male and female reproductive success in Cestrum parqui (Solanaceae). Oecologia 138: 513-520.

Aguilar, R., L. Ashworth, L. Galetto \& M.A. Aizen. 2006. Plant reproductive susceptibility to habitat fragmentation: review and synthesis through a meta-analysis. Ecol. Lett. 9: 968-980.

Aizen, M.A. \& P. Feinsinger. 1994a. Fragmentation, pollination and plant reproduction in a Chaco Dry Forest. Argentina. Ecology 75: 330-351.

Aizen, M.A. \& P. Feinsinger. 1994b. Habitat fragmentation, native insect pollinators and feral honey bees in Argentine Chaco Serrano. Ecol. Appl. 4: 378-392.

Almeida, M.C. \& S. Laroca. 1988. Trigona spinipes (Apidae, Meliponinae): Taxonomia, bionomia e relações tróficas em áreas restritas. Acta Biol. Par. 17: 67-108.

Bencke, C.S.C. \& L.P.C. Morrelato. 2002. Comparação de dois métodos de avaliação da fenologia de plantas, sua interpretação e representação. Rev. Bras. Bot. 25: 269-275.

Bissonette, J.A. \& I. Storch. 2002. Fragmentation: is the message clear? Conserv. Ecol. 6: 14 (Also available on line: www.consecolorg/vol6/iss2/art14).

Borchert, R. 1992. Computer simulation of tree growth periodicity and climatic hydroperiodicity in tropical forest. Biotropica 24: 385-395.

Brasil. 2000. SNUC Lei $n^{\circ} 9985$, de 18 de julho de 2000 Institui o Sistema Nacional de Unidades de Conservação e dá outras providências. Brasília, DF. (Downloaded: February 3, 2008, www.planaltogovbr/ccivil/ leis/L9985htm).

Brown, K.A., J.C. Ingram, D.F.B. Flynn, R. Razafindrazaka \& V. Jeannoda. 2009. Protected area safeguard tree and shrub communities from degradation and invasion: a case study in eastern Madagascar. Environ. Manag. 44: 136-148.

Buchman, S.L. 1983. Buzz pollination in angiosperms, p. 73-113. In C.E. Jones \& R.J. Little (eds.). Handbook of experimental pollination biology. Scientific and academic editions, New York, New York, USA. 
Cane, J. 2001. Habitat fragmentation and native bees: a premature verdict? Conserv. Ecol. 5: 149-161.

Carvalho, P.E.R. 2004. Pau-Cigarra - Senna multijuga. Circular técnica 92: 1-11. (Downloaded: February 10, 2011, www.cnpf.embrapa.br/publica/circtec/edicoes/ circ-tec92.pdf).

Cascante, A., M. Quesada, J.J. Lobo \& E.A. Fuchs. 2002. Effects of dry tropical forest fragmentation on the reproductive success and genetic structure of the tree Samanea saman. Conserv. Biol. 16: 37-147.

Dick, C.W. 2001. Genetic rescue of remmant tropical trees by alien pollinator. Proc. Roy. Soc. Lond. B. Biol. Sci. 268: 2391-2396.

Dudley, N. 2008. Guidelines for applying protected area management categories. IUCN, Gland, Nyon, Switzerland.

Dunley, B., L. Freitas \& L. Galetto. 2009. Reproduction of Byrsonima sericea (Malpighiaceae) in Restinga fragmented habitats in Southeastern Brazil. Biotropica 41: 1-8.

Fournier, L.A. 1974. Un método cuantitativo para la medición de características fenolólogicas en árboles. Turrialba 24: 422-423.

Frankie, G.N., H.G. Baker \& P.A. Opler. 1974. Comparative phenological studies of trees in tropical wet and dry forest in the lowlands of Costa Rica. J. Ecol. 62: 881-913.

Gaston, K.J., K. Charman, S.F. Jackson, P.R. Armsworth, A. Bonn, R.A. Briers, C.S.Q. Callaghan, R. Catchpole, J. Hopkins, W.E. Kunin, J. Latham, P. Opdam, R. Stoneman, D.A. Stroud \& R. Tratt. 2006. The ecological effectiveness of protected areas: The United Kingdom. Biol. Conserv. 132: 76-87.

Gaston, K.J., S.F. Jackson, L. Cantú-Salazar \& G. CruzPiñon. 2008. The ecological performance of protected areas. Ann. Rev. Ecol. Evol. Systemat. 39: 93-113.

Ghazoul, J., K. Liston \& T.J.B. Boyle. 1998. Disturbanceinduced density-dependent seed set in Shorea siamensis (Dipterocarpaceae), a tropical forest tree. J. Ecol. 86: 462-473.

Gigord, L., F. Picot \& J.A. Shykoffb. 1999. Effects of habitat fragmentation on Dombeya acutangula (Sterculiaceae), a native tree on La Réunion (Indian Ocean). Biol. Conserv. 88: 43-51.

Goulson, D., G.C. Lye \& B. Darwill. 2008. Decline and conservation of bumblebees. Ann. Rev. Entomol. 53: 191-208.
Harper, J.L. 1977. Population biology of plants. Academic, New York, New York, USA.

Herrerías-Diego, Y., M. Quesada, K.E. Stoner, J.A. Lobo, Y. Hernández-Flores \& G.S. Montoya. 2008. Effect of forest fragmentation on fruit and seed predation of the tropical dry forest tree Ceiba aesculifolia. Biol. Conserv. 141: 241-248.

Hockings, M. 2003. Systems for assessing the effectiveness of management in protected areas. BioScience 53: 823-832.

Irwin, M.S. \& R.C. Barneby. 1982. The american Cassinae a synoptical revision of Leguminosae tribe Cassieae subtribe Cassinae in the New World. Mem. New York Bot. Gard. 35: 1-918.

Kalil-Filho, N.A., A.F. Santos, A.P. Carvalho, A.C. Medeiros, A.R. Ferratti, A.C. Nogueira, C.A. Ferreira \& P.E.R. Carvalho. 2002. Espécies recomendadas para a restauração da Mata Atlântica, p. 77-130. In A.P.M. Galvão \& A.C.S. Medeiros (eds.). Restauração da Mata Atlântica em áreas de sua primitiva ocorrência natural. Embrapa, Colombo, Paraná, Brasil.

Kolb, A., R. Leimu \& J. Ehrlén. 2007. Environmental context influences the outcome of a plant-seed predator interaction. Oikos 116: 864-872.

Laurance, W.F. 2009. Conserving the hottest of the hotspots Biol. Conserv. 142: 1137.

Lewis, O.T. \& Y. Basset. 2007. Insect conservation in tropical forest, p 34-56. In A.J.A. Stewart, T.R. New \& O.T. Lewis (eds.). Insect Conservation Biology. CABI, Wallingford, Oxfordshire, United Kingdom.

Lopes, L.E. \& S. Buzato. 2007. Variaton in pollinator assemblages in a fragmented landscape and its effects on reproductive stages of a self-incompatible treelet, Psychotria suterella (Rubiaceae). Oecologia 154: 305-314.

Mendonça-Filho, C.V. 1996. Braúna, angico, jacarandá e outras leguminosas de Mata Atlântica: Estação Biológica de Caratinga, Minas Gerais. Fundação Botânica, Margaret Mee, Fundação Biodiversitas, AP.EBC, IEF, FZB-BH, SB-MG, Belo Horizonte, Minas Gerais, Brasil.

Metzger, J.P. 2009. Conservation issues in the Brazilian Atlantic forest. Biol. Conserv. 142: 1138-1140.

Murcia, C. 1995. Edge effects in fragmented forests: implications for conservation. Trees 10: 58-62. 
Myers, N., R.A. Mittermeier, C.G. Mittermeier, G.A.B. da Fonseca \& J. Kent. 2000. Biodiversity hotspots for conservation priorities. Nature 403: 853-858.

Newstrom, L.E., G.W. Frankie \& H.G. Baker. 1994. A new classification for plant phenology based on flowering patterns in lowland tropical rain forest trees at $\mathrm{La}$ Selva, Costa Rica. Biotropica 26: 141-159.

Pauw, A. 2007. Collapse of a pollination web in small conservation areas. Ecology 88: 1759-1769.

Ramos, F.N. \& F.A.M. Santos. 2006. Floral visitors and pollination of Psychotria tenuinervis (Rubiaceae): distance from the anthropogenic and natural edges of an Atlantic forest fragment. Biotropica 39: 383-389.

Ribeiro, M.C., J.P. Metzger, A.C. Martensen, F.J. Ponzoni \& M.M. Hirota. 2009. The Brazilian Atlantic forest: How much is left, and how is the remaining forest distributed? Implications for conservation. Biol. Conser. 142: 1141-1153.

Sari, L.T. \& C.S. Ribeiro-Costa. 2005. Predação de sementes de Senna multijuga (Rich) HS Irwin and Barneby (Caesalpinaceae) por bruquídeos (Coleóptera: Chrysomelidae). Neotrop. Entomol. 34: 521-525.

Sari, L.T., C.S. Ribeiro-Costa \& J. Roper. 2005. Dinâmica populacional de bruquíneos Coleoptera: Chrysomelidae) em Senna multijuga L.C. Richard I. \& B. (Caesalpinaceae). Rev. Bras. Zool. 22: 169-174.

Saunders, D.A., R.J. Hobbs \& C.R. Margules. 1991. Biological consequences of ecosystem fragmentation: a review. Biol. Conserv. 5: 18-32.

Scarano, F.R. 2007. Perspectives on biodiversity science in Brazil. Sciencia Agricola 64: 439-447.

Segadas-Vianna, F. \& L. Dau. 1965. Ecology of Itatiaia range, southeastern Brazil II, Climates and altitudinal climatic zonation. Arquivos do Museu Nacional Rio de Janeiro 53: 31-53.

Srivastava, D.S. \& M. Vellend. 2005. Biodiversity-ecosystem function research: Is it relevant to conservation? Ann. Rev. Ecol. Evol. Systemat. 36: 267-294.

StatSoft. 2001. STATISTICA: Data Analysis Software System version 60. StatSoft, Oklahoma, USA.

Steffan-Dewenter, I. \& S. Schiele. 2008. Do resources or natural enemies drive bee population dynamics in fragmented habitats? Ecology 89: 1375-1387.

Steffan-Dewenter, I., U. Münzenberg \& T. Tscharntke. 2001. Pollination, seed set and seed predation. Proc. Roy. Soc Lond. B. Biol. Sci. London B. 268: 1685-1690.

Steffan-Dewenter, I., U. Münzenberg, C. Büerger, C. Thies \& T. Tscharntke. 2002. Scale-dependent effects of landscape context on three pollinator guilds. Ecology 83: 1421-1432.

Tscharntke, T., A. Gathmann \& I. Steffan-Dewenter. 1998. Bioindication using trap-nesting bees and wasps and their natural enemies: community structure and interactions. J. Appl. Ecol. 35: 708-719.

Umetsu, F. \& R. Pardini. 2007. Small mammals in a mosaic of forest remmants and anthropogenic habitats - evaluating matrix quality in an Atlantic forest landscape. Landsc. Ecol. 22: 517-530.

Veloso, H.P., A.L.R. Rangel-Filho \& J.C.A. Lima. 1991. Classificação da vegetação brasileira, adaptada a um sistema universal. Instituto Brasileiro de Geografia e Estatística, Rio de Janeiro, Rio de Janeiro, Brasil.

Wolowski, M. \& L. Freitas. 2010. Sistema reprodutivo e polinização de Senna multijuga (Fabaceae) em Mata Atlântica Montana. Rodriguésia 61: 167-179. 